\title{
Strategi Pemasaran Lele Sangkuriang Organik Surya Kencana Farm Kota Bogor
}

\author{
Marketing Strategy Organic Sangkuriang Catfish Surya Kencana Farm Bogor
}

\author{
Raissa Rahmaditya Rabilla ${ }^{1 *}$, Arif Satria ${ }^{2 \sharp}$, dan Lilik Noor Yuliati ${ }^{3 \sharp}$
}

${ }^{1}$ Sekolah Bisnis Institut Pertanian Bogor

Jl. Raya Pajajaran, Kampus IPB Gunung Gede Bogor 16151

${ }^{2}$ Departemen SKPM, Fakultas Ekologi Manusia, Institut Pertanian Bogor

${ }^{3}$ Departemen Ilmu Keluarga dan Konsumen, Fakultas Ekologi Manusia, Institut Pertanian Bogor

* Jl. Kamper, Wing 4 Level 5, Kampus IPB Dramaga, Bogor 16680

\begin{abstract}
ABSTRAK
Ikan Lele merupakan salah satu ikan air tawar yang paling banyak dibudidayakan. Bogor merupakan kabupaten dan kota yang memiliki potensi cukup besar untuk budidaya Lele. Hal ini dikarenakan konsumsi ikan Lele cukup banyak diserap oleh wilayah DKI Jakarta dan kota Bogor menjadi penyedianya. Pada tahun 2016 saja, tingkat konsumsi ikan Lele di wilayah Jakarta, Bogor, Depok, Tangerang dan Bekasi (Jabodetabek) sangat tinggi. Kebutuhan masyarakat Jabodetabek akan ikan Lele mencapai 120 ton per harinya. Seperti dikutip dari sebuah artikel, dari jumlah kebutuhan tersebut, Bogor baru dapat menghasilkan ikan Lele 30 ton per hari. Hal ini tentu saja menjadi peluang dan menjadi prospek bagi budidaya Lele. Penelitian ini bertujuan untuk mengidentifikasi kondisi lingkungan internal dan eksternal di Surya Kencana Farm. Merumuskan alternatif strategi pemasaran bagi Surya Kencana Farm. Menentukan prioritas strategi pemasaran bagi Surya Kencana Farm. Penelitian ini menggunakan analisis Strength Weakness Opportunities and Threat (SWOT) untuk menentukan pilihan alternatif strategi pemasaran bagi Surya Kencana Farm dan (QSPM) untuk menentukan strategi terbaik yang dapat dilakukan Surya Kencana Farm. Hasil analisis dengan matriks SWOT dan QSPM, diperoleh alternatif strategi yang dapat diimplementasikan, yaitu memanfaatkan kemajuan TI, seperti website dan internet untuk menginformasikan mutu produk Lele Sangkuriang, serta menginformasikan mengenai Lele Sangkuriang organik yang diproduksi SKF merupakan prioritas strategi yang dapat dilakukan oleh SKF.
\end{abstract}

Kata kunci: lele, pemasaran, QSPM, strategi, SWOT

\begin{abstract}
Catfish is one of the most widely cultivated freshwater fish. Bogor is a district and a city that has considerable potential for Catfish farming. This is because the consumption of Catfish is pretty much absorbed by the DKI Jakarta and Bogor city become penyedianya. In 2016 alone, the level of consumption of Catfish in Jakarta, Bogor, Depok, Tangerang and Bekasi (Jabodetabek) is very high. The needs of Jabodetabek community will Catfish reaches 120 tons per day. As quoted from an article, from the amount of these needs, Bogor can only produce Catfish as much as 30 tons per day. This of course becomes an opportunity and a prospect for Catfish farming. This study aims to identify the condition of internal environment and external environment in Surya Kencana Farm. Formulate alternative marketing strategies for Surya Kencana Farm. Determining priority marketing strategy for Surya Kencana Farm. This study uses SWOT analysis to determine alternative choice of marketing strategy for Surya Kencana Farm. Then proceed with QSPM to determine the best strategy that Surya Kencana Farm can do. The results of the analysis with the SWOT and QSPM matrices, obtained alternative strategies that can be implemented, namely utilizing IT progress, such as websites and the internet to inform Lele Sangkuriang product quality, and informing about organic Sangkuriang Catfish produced by SKF is a priority strategy that can be done by SKF.
\end{abstract}

Key words: catfish, marketing, QSPM, strategy, SWOT

\footnotetext{
*) Korespondensi:

Jl. Drupada 2 Nomor 8 Indraprasta Bogor; email: raissarabilla@yahoo.com; Hp: 08111131327
} 


\section{PENDAHULUAN}

Menurut KKP (2015) usaha budidaya ikan terutama ikan air tawar semakin hari semakin menjanjikan. Menurut laporan Badan Pangan PBB, pada tahun 2021 konsumsi ikan per kapita penduduk dunia akan mencapai $19,6 \mathrm{~kg}$ per tahun. Walaupun saat ini konsumsi ikan masih lebih banyak dipenuhi oleh produksi ikan laut, akan tetapi pada tahun 2018 produksi ikan air tawar akan menyusul bahkan melebihi produksi perikanan tangkap. Hal ini dikarenakan produksi perikanan tangkap akan mengalami penurunan akibat overfishing atau habis karena terlalu banyak yang ditangkap. Ikan di laut akan menjadi semakin sulit didapatkan. Bahkan hal terburuk yang diramalkan para peneliti pada tahun 2048 tidak ada lagi ikan untuk ditangkap.

Indonesia yang merupakan negara kepulauan dan dengan jumlah penduduk yang sangat besar dapat dijadikan prospek pasar potensial untuk produk perikanan. Pada survei tingkat nasional, dapat dilihat bahwa tingkat konsumsi ikan per kapita dalam enam tahun terakhir yaitu tahun 2011-2016 mengalami kenaikan sebesar 6,3\%. Pada tahun 2016 tingkat konsumsi ikan nasional 43,94 kg per kapita per tahun atau naik 6,8\% dari tahun sebelumnya. Walaupun mengalami kenaikan, nilai ini masih jauh lebih rendah dibandingkan dengan beberapa negara Assosiation of South East Asia Nation (ASEAN), seperti Malaysia yang telah mencapai $56,2 \mathrm{~kg}$ per kapita per tahun dan Singapura yang telah mencapai $48,9 \mathrm{~kg}$ per kapita per tahun. Dalam hal ini Indonesia berada di posisi ketiga. Kondisi ini menjadi ironi bagi bangsa yang kaya akan sumber protein. Bahkan nilai ini sangat jauh lebih rendah bila dibandingkan dengan Jepang yang mendekati $100 \mathrm{~kg}$ per kapita per tahun. Tren konsumsi ikan per kapita di Indonesia cenderung mengalami kenaikan mengindikasikan bahwa masyarakat Indonesia telah mengalami pergeseran pola konsumsi sebagaimana negara-negara lain di dunia (KKP, 2018).

Salah satu jenis ikan air tawar yang memiliki potensi cukup besar dan banyak digemari oleh masyarakat adalah ikan Lele (Clarias $s p$ ), terutama di pulau Jawa. Ikan Lele banyak digemari karena memiliki rasa gurih dan renyah. Selain itu, harganya termasuk murah dan lebih terjangkau, sehingga ikan Lele lebih digemari dibandingkan jenis ikan lainnya. Peternak menyukai usaha budidaya ikan ini karena waktu perawatannya mudah dan cepat besar dan tergolong singkat.
Jawa Barat merupakan salah satu provinsi di Indonesia yang menghasilkan produk perikanan perairan umum yang cukup tinggi yaitu termasuk dalam peringkat keenam penghasil ikan perairan umum terbesar di Indonesia dari 33 provinsi di Indonesia. Hal ini membuktikan bahwa Jawa Barat merupakan provinsi terbesar di Pulau Jawa yang memproduksi ikan perairan umum.

Ikan Lele merupakan salah satu ikan air tawar yang paling banyak dibudidayakan dimana Bogor merupakan kabupaten dan kota yang memiliki potensi cukup besar untuk budidaya tersebut. Hal ini dikarenakan konsumsi ikan Lele cukup banyak diserap oleh wilayah DKI Jakarta dan kota Bogor menjadi penyedianya. Pada tahun 2016, tingkat konsumsi ikan Lele di wilayah Jakarta, Bogor, Depok, Tangerang dan Bekasi (Jabodetabek) sangat tinggi. Kebutuhan masyarakat Jabodetabek akan ikan Lele mencapai 120 ton per harinya. Seperti dikutip dari sebuah artikel, dari jumlah kebutuhan tersebut, Bogor baru dapat menghasilkan ikan Lele 30 ton per hari. Hal ini menjadi peluang dan prospek bagi budidaya Lele.

Dedi (2014) menyatakan bahwa ikan Lele merupakan salah satu jenis ikan air tawar yang cukup banyak digemari masyarakat dikarenakan harganya relatif murah, mudah dibudidayakan dan tentunya memiliki kandungan gizi tinggi. Nugroho 2007 dalam Jaja (2012) menyatakan bahwa penguasaan pasar menjadi hal penting dari sekian banyak hal dalam usaha ikan. Interaksi dengan sesama pembudidaya ikan Lele menjadi sangat penting untuk menunjang keberhasilan pembesaran dan pemasaran ikan Lele. sesama pembudidaya Lele dapat bertukar informasi mengenai benih yang baik, pakan bermutu, dan pasar yang pembayarannya tunai.

Pemerintah dalam beberapa tahun ini terus menggalakkan program demi meningkatnya tingkat konsumsi masyarakat akan ikan. Apabila terjadi peningkatan konsumsi masyarakat akan ikan, maka memberikan manfaat yang pertama untuk meningkatkan mutu Sumber Daya Manusia (SDM) Indonesia, karena ikan mengandung protein dan bergizi tinggi. Selain itu, peningkatan konsumsi ikan akan mendorong pengembangan usaha ikan Lele di Indonesia, khususnya dalam aspek pemasaran dan pengolahan (Jatnika, 2011).

Julisar dan Miranda (2013) menjelaskan salah satu kunci keberhasilan Usaha Kecil dan Menengah (UKM) adalah tersedianya pasar yang jelas bagi produk UMKM. Akan tetapi, kelemahan mendasar yang sering dihadapi UMKM dalam bidang pemasaran adalah orientasi pasar rendah, 
lemah dalam persaingan yang kompleks dan tajam, serta infrastruktur pemasaran yang tidak memadai. Setyorini (2018) menjelaskan beberapa faktor yang mempengaruhi lambannya peningkatan produksi dan pemasaran pindang higienis di Cindy Group sebagai UMKM yang memasarkan produk perikanan dikarenakan tidak adanya tenaga pemasaran khusus yang menangani produk pindang higienis di manajemen Cindy Group. Tingkat produksi dan penjualan yang tidak stabil, terutama pada jenis pindang higienis memacu Cindy Group mencari strategi pemasaran yang tepat untuk berkembang menjadi perusahaan lebih besar dan menghadapi persaingan dari usaha sejenis.

Sofyan (2003) menyatakan bahwa peningkatan hasil produksi perikanan sangat ditentukan oleh berbagai unsur, yaitu nelayan, armada, dan alat penangkapan. Selain itu, hal yang tidak kalah pentingnya adalah SDM, modal, mutu produk, penentuan harga, unit-unit pemasaran, akses pemasaran, serta sistem pemasaran dan teknologi. Lebih lanjut dikatakan bahwa semakin maraknya persaingan membuat peranan pemasaran semakin penting dan merupakan ujung tombak bagi perusahaan dalam meraih keberhasilan. Kegiatan pemanfaatan sumber daya ikan tidak akan menghasilkan nilai ekonomis tinggi, jika tidak dibarengi dengan kegiatan pemasaran yang baik. Kemampuan produksi tinggi tidak akan menjadi berarti, apabila tidak didukung oleh sistem pemasaran yang tepat. Pemilihan strategi pemasaran yang tepat akan membuat perusahaan berkembang dan menjadi bisnis yang menguntungkan (Suhendar, 2009). Menurut Sulistyowati (2017), persaingan pemasaran ikan Lele yang ketat di pasar menjadi dasar dari penelitian menganalisis strategi pemasaran. Strategi pemasaran juga diperlukan oleh Surya Kencana Farm yang merupakan salah satu usaha pembenihan dan pemasaran ikan Lele Sangkuriang di Kota Bogor.

Penelitian ini bertujuan mengidentifikasi kondisi lingkungan internal dan eksternal di Surya Kencana Farm (SKF), merumuskan alternatif strategi pemasaran bagi Surya Kencana Farm, dan menentukan prioritas strategi pemasaran bagi SKF. Penelitian ini menggunakan analisis (SWOT) untuk menentukan pilihan alternatif strategi pemasaran bagi SKF dan Quantitative Strategic Planning Matrix (QSPM) untuk menentukan strategi terbaik yang dapat dilakukan SKF.

Penelitian ini difokuskan pada strategi pemasaran Lele yang diproduksi oleh SKF di Curug, Kecamatan Bogor Barat, Kota Bogor.
Produk Lele yang dihasilkan SKF merupakan produk Lele Sangkuriang organik.

\section{METODE PENELITIAN}

Penelitian ini dilakukan di usaha pembesaran ikan Lele Sangkuriang yang berada di Kota Bogor dengan nama SKF. Surya Kencana Farm berada di Jl. Curug Induk No.52 Semplak, Bogor Barat, Kota Bogor, Jawa Barat. Pemilihan lokasi penelitian ini dilakukan secara sengaja (purposive) mengingat SKF merupakan usaha pembesaran ikan Lele Sangkuriang yang berada di Kota yang baru berdiri sekitar 2 tahun. Waktu pengumpulan data dilakukan pada bulan April sampai dengan bulan Mei 2018.

\section{Pengumpulan Data}

Data yang digunakan dalam penelitian ini berasal dari data primer dan sekunder. Data primer merupakan data hasil wawancara, kuesioner, dan observasi langsung di lapangan. Data sekunder diperoleh dari instansi yang terkait dengan penelitian ini seperti Badan Pusat Statistik (BPS), Direktorat Jenderal Perikanan, Perpustakaan LSI IPB, serta jurnal dan artikel elektronik yang terkait dengan penelitian. Informasi tambahan yang mendukung penelitian ini menggunakan literatur-literatur yang relevan dengan obyek permasalahan.

Narasumber internal merupakan responden yang berasal dari lingkungan perusahaan SKF, yaitu pemilik perusahaan yang berjumlah satu orang dan karyawan yang berjumlah dua orang. Narasumber internal dipilih berdasarkan pengetahuannya mengenai SKF, memiliki kewenangan dalam perumusan, serta pelaksanaan program strategi, dan ikut serta dalam pelaksanaan kegiatan di SKF. Narasumber eksternal adalah pakar atau para ahli seperti dari kepemerintahan, yaitu Balai Penelitian dan Kota Bogor yang berjumlah dua orang yang merupakan peneliti utama. Hal ini dilakukan karena lokasi SKF yang berada di Kota Bogor dan bergerak dalam bidang perikanan budidaya air tawar.

Dalam merumuskan strategi pemasaran, penelitian ini menggunakan pendekatan tahap pertama yang dilakukan dengan melakukan analisis lingkungan internal atau Internal Factor Evaluation (IFE) dan eksternal atau External Factor Evaluation (EFE). Selanjutnya dilakukan analisis SWOT (Strengths, Weaknesses, Opportunities dan Threats) dengan berdasarkan faktor internal 
(kekuatan dan kelemahan) serta eksternal (peluang dan ancama) yang diperoleh sebelumnya. Data yang diperoleh dianalisis dengan menggunakan analisis deskriptif, sedangkan data kuantitatif dianalisis dengan menggunakan matriks IFE, EFE dan SWOT.

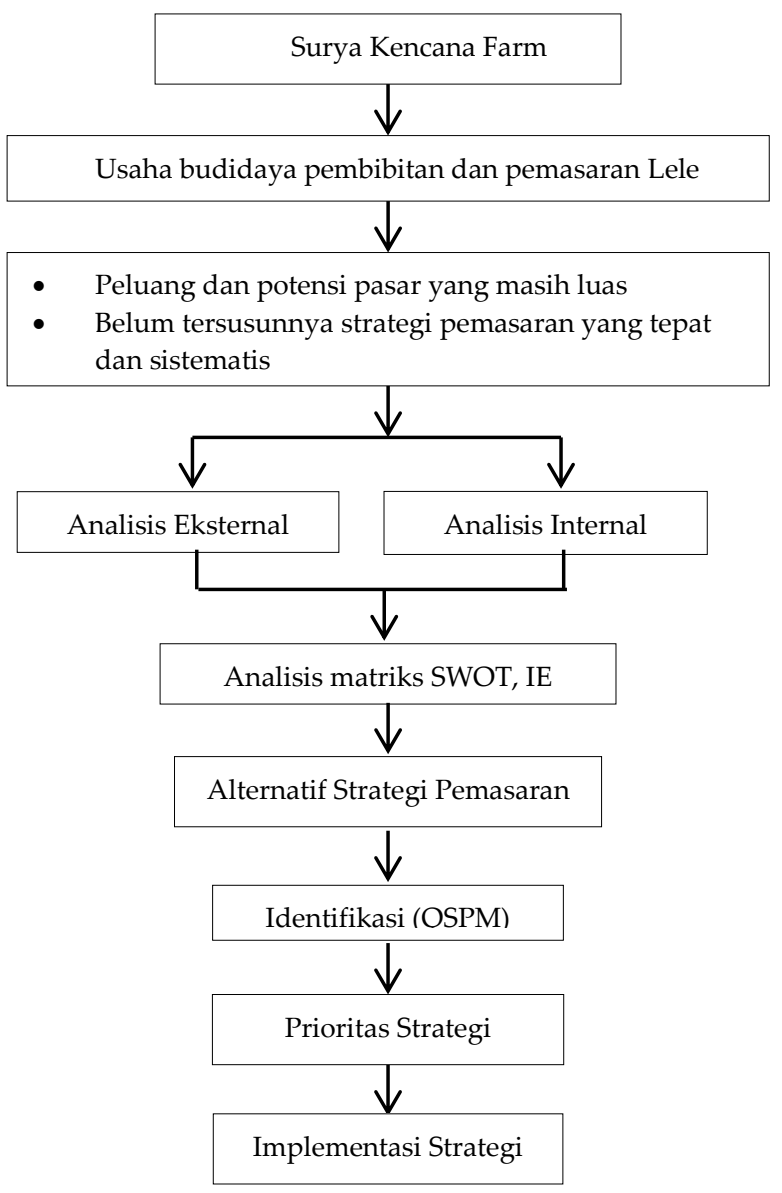

Gambar 1. Kerangka pemikiran penelitian

Setelah tahapan-tahapan sebelumnya dibuat dan dianalisa, maka tahap selanjutnya menyusun daftar prioritas yang harus di implementasikan. Quantitative Strategic Planning Matrix (QSPM) merupakan teknik yang secara obyektif untuk menetapkan alternatif strategi yang diprioritaskan. QSPM merupakan alat untuk menentukan atau merekomendasikan pilihan strategi atas dasar pendapat ahli atau praktisi (expert choice). QSPM juga melibatkan unsur intuisi (intuitive judgement) didasari oleh Key Success Factors (KSF) internal dan eksternal terpilih untuk menetapkan pilihan yang paling menarik, terpercaya dan layak diterapkan atau secara konseptual disebut sebagai upaya menetapkan relative attractiveness (David, 2006 dan Rangkuti, 2008).

Kerangka pemikiran operasional digunakan sebagai landasan mengenai langkah-langkah yang harus dilakukan dalam penelitian. Kerangka pemikiran pada penelitian ini didasarkan pada kegiatan-kegiatan yang dilakukan oleh Surya Kencana Farm dalam pemasaran Lele.

\section{HASIL DAN PEMBAHASAN}

\section{Identifikasi Faktor Internal dan Eksternal}

Analisis matriks IFE dan EFE dilakukan terhadap lingkungan internal dan eksternal SKF, sehingga diperoleh faktor-faktor kunci yang termasuk ke dalam kekuatan, kelemahan, peluang dan ancamannya. Skor yang diperoleh dari matriks tersebut menunjukkan kemampuan usaha dalam memanfaatkan kekuatan dan mengatasi kelemahan yang dimiliki, serta menunjukkan kemampuan dalam meraih peluang dan mengatasi ancaman eksternalnya.

IFE meliputi kekuatan dan kelemahan dilakukan dengan pembobotan dan pemberian rating berdasarkan penilaian yang dilakukan oleh SKF. Dalam strategi pemasaran, analisis lingkungan internal dapat pula terdiri dari bauran pemasaran SKF.

Penilaian pembobotan dan pemberian rating bersifat subyektif yang memuat kondisi aktual dan sudut pandang dalam menghadapi berbagai faktor internal. Skor terbobot total pada evaluasi faktor internal menentukan posisi perusahaan dalam menghadapi kelemahan berdasarkan kekuatan yang dimiliki.

EFE meliputi peluang dan ancaman, dilakukan dengan pembobotan dan pemberian rating berdasarkan penilaian yang dilakukan oleh SKF. Penilaian pembobotan dan pemberian rating bersifat subyektif yang memuat kondisi aktual dan sudut pandang dalam menghadapi berbagai faktor eksternal. Nilai atau skor terbobot total pada evaluasi faktor eksternal menentukan posisi perusahaan dalam menghadapi ancaman berdasarkan peluang yang dimiliki.

Berdasarkan matriks EFE, diperoleh skor 2,36. Hal ini menunjukkan SKF berada di rataan. Skor total yang terdapat pada matriks EFE menggambarkan dan mengindikasikan posisi strategi SKF stabil dalam merespon situasi eksternal yang dihadapi. Hasil pembobotan dan pemberian rating dapat menjelaskan peluang dan ancaman yang dihadapi SKF. Kemajuan teknologi pemasaran yang semakin berkembang memiliki bobot pada faktor peluang 0,13 dengan tingkat kepentingan atau rating 4 yang artinya sangat berpeluang. Dapat dilihat bahwa kemajuan teknologi pemasaran semakin berkembang menjadi 
peluang bagi SKF. SKF telah menggunakan teknologi internet sebagai pemasaran, akan tetapi masih terus diupayakan aagar maksimal.

Kenaikan harga pakan bagi SKF memiliki bobot terbesar pada faktor ancaman, yaitu 0,15 dengan tingkat kepentingan atau rating 1 yang artinya sangat mengancam. Hal tersebut menunjukkan kenaikan harga pakan sangat berpengaruh terhadap aktivitas penjualan SKF, dikarenakan kenaikan harga pakan akan berpengaruh terhadap harga jual dari produk Lele Sangkuriang organik SKF.

\section{Analisis SWOT}

Perumusan strategi dilakukan melalui identifikasi dan analisis faktor internal yang terdiri dari kekuatan dan kelemahan, serta faktor eksternal yang terdiri dari peluang dan ancaman. Kekuatan merupakan kompensasi khusus yang memberikan keunggulan komparatif bagi SKF, sedangkan kelemahan merupakan keterbatasan atau kekurangan dalam sumber daya keterampilan, maupun kemampuan yang menghambat kinerja SKF. Peluang merupakan situasi yang diinginkan atau disukai dalam lingkungan industri. Ancaman merupakan situasi yang tidak diinginkan atau tidak disukai dalam lingkungan industri. Perumusan strategi dilakukan dengan mengkombinasikan berbagai faktor yang telah diidentifikasi dan dikelompokkan. Hasil perumusan dikelompokkan menjadi empat kelompok perumusan strategi yang terdiri dari strategi Kekuatan-Peluang (S-O), strategi Kekuatan-Ancaman (S-T), Strategi Kelemahan-Peluang (W-O) dan strategi Kelemahan-Ancaman (W-T) (Gambar 2).

\section{Pemilihan Strategi berdasar QSPM}

Berdasarkan hasil perhitungan dalam matriks QSP, diperoleh strategi paling tepat diimplementasikan, yaitu memanfaatkan kemajuan Teknologi Informasi (TI) seperti website dan internet untuk menginformasikan kualitas produk Lele Sangkuriang, serta menginformasikan mengenai Lele Sangkuriang organik yang diproduksi SKF. Hal ini dapat dilakukan dengan memaksimalkan website yang telah dibuat oleh SKF. Selain itu, dapat pula memanfaatkan media sosial seperti instagram, facebook dan lain sebagainya.

\begin{tabular}{|c|c|c|}
\hline Eksternal & $\begin{array}{l}\text { Kekuatan (S) } \\
\text { 1. Mutu produk tinggi } \\
\text { 2. SDM yang bermutu dan terlatih } \\
\text { 3. Lokasi cukup strategis } \\
\text { 4. Harga cukup terjangkau }\end{array}$ & $\begin{array}{l}\text { Kelemahan }(\mathbf{W}) \\
\text { 1. Pemasaran melalui internet } \\
\text { belum optimal } \\
\text { 2. SDM masih terbatas, sehingga } \\
\text { bagian pemasaran belum } \\
\text { memadai } \\
\text { 3. Promosi tidak dilakukan secara } \\
\text { optimal } \\
\text { 4. Belum dapat menjangkau } \\
\text { pasar lebih luas }\end{array}$ \\
\hline $\begin{array}{l}\text { Peluang (O) } \\
\text { 1. Kemajuan teknologi } \\
\text { pemasaran yang semakin } \\
\text { berkembang } \\
\text { 2. Dukungan Pemerintah melalui } \\
\text { kebijakan GEMARIKAN } \\
\text { 3. Pengetahuan masyarakat } \\
\text { mengenai nutrisi pada ikan } \\
\text { Lele } \\
\text { 4. Gaya hidup masyarakat untuk } \\
\text { hidup sehat } \\
\text { 5. Kemajuan teknologi produksi } \\
\text { Lele }\end{array}$ & $\begin{array}{l}\text { Strategi (S-O) } \\
\text { 1. Memanfaatkan kemajuan Teknologi } \\
\text { Informasi (TI) untuk } \\
\text { menginformasikan kualitas produk } \\
\text { Lele Sangkuriang serta } \\
\text { menginformasikan mengenai Lele } \\
\text { Sangkuriang organik yang } \\
\text { diproduksi SKF (S1,S2, O1, O4, O5) } \\
\text { 2. Meningkatkan kerjasama dengan } \\
\text { pemerintah dalam pemasaran Lele } \\
\text { organik (S3, S4, O2, O3, O4) } \\
\text { 3. Memperluas jaringan pemasaran (S2, } \\
\text { S3, O3, O1) }\end{array}$ & $\begin{array}{l}\text { Strategi (W-O) } \\
\text { 1. Memaksimalkan dukungan } \\
\text { pemerintah yang diberikan } \\
\text { untuk menjangkau pasar lebih } \\
\text { luas (W1,W3, W4, O1, O2, O3, } \\
\text { O4) } \\
\text { 2. Memanfaatkan kemajuan } \\
\text { teknologi untuk memasarkan } \\
\text { produk ke masyarakat (W1, } \\
\text { W2, W3, O1, O3, O4, O5) } \\
\text { 3. Membentuk divisi pemasaran } \\
\text { secara khusus (W1, W2, W3, } \\
\text { O1, O3, O4) }\end{array}$ \\
\hline $\begin{array}{l}\text { Ancaman }(\mathrm{T}) \\
\text { 1. Pandangan masyarakat } \\
\text { terhadap Lele } \\
\text { 2. Kelangkaan bahan baku } \\
\text { 3. Keberadaan produk substitusi } \\
\text { 4. Kenaikan harga pakan }\end{array}$ & $\begin{array}{l}\text { Strategi (S-T) } \\
\text { 1. Mempertahankan mutu Lele } \\
\text { Sangkuriang organik (S1,S2, S4, } \\
\text { T1,T3) } \\
\text { 2. Melakukan kontrak kerjasama } \\
\text { dengan pemasok pakan (S2, S3, T2, } \\
\text { T4) }\end{array}$ & $\begin{array}{l}\quad \text { Strategi }(\mathbf{W}-\mathrm{T}) \\
\text { Memperbaiki sistem manajemen } \\
\text { dengan menambah tenaga kerja } \\
\text { menurut tanggung jawab } \\
\text { pekerjaan yang dibutuhkan (W1, } \\
\text { W2, W3, T3) }\end{array}$ \\
\hline
\end{tabular}




\section{Implikasi Manajerial}

Hasil analisis SWOT (Gambar 2), diperoleh sembilan alternatif strategi yang dapat dimplementasikan sebagai strategi pemasaran dari Surya Kencana Farm. Dari sembilan alternatif strategi tersebut, memanfaatkan kemajuan TI, seperti website dan internet untuk menginformasikan mutu produk Lele Sangkuriang, serta menginformasikan mengenai Lele Sangkuriang organik yang diproduksi SKF merupakan prioritas strategi yang dapat dilakukan oleh SKF. SKF dapat melakukan kegiatan promosi melalui website yang telah dibuat. Promosi juga dapat dilakukan melalui social media melalui instagram ataupun facebook. Kemudahan pemesanan online juga dapat menjadi cara untuk memanfaatkan kemajuan TI. Penerapan alternatif strategi yang telah dipaparkan di atas dikembalikan kepada perusahaan dalam pelaksanaannya.

\section{KESIMPULAN}

Strategi prioritas untuk diterapkan dalam pemasaran produk Lele Sangkuriang organik yang dapat diterapkan oleh SKF, yaitu memanfaatkan kemajuan TI seperti website dan internet untuk menginformasikan mutu produk Lele Sangkuriang, serta menginformasikan mengenai Lele Sangkuriang organik yang diproduksi SKF; Meningkatkan kerjasama dengan pemerintah dalam pemasaran Lele organik, serta memperluas jaringan pemasaran.

\section{DAFTAR PUSTAKA}

David, F.R. 2006. Strategic Management: Concept and Case. 10th Ed. New Jersey: Pearson. Diterjemahkan oleh Ichsan Stiyo Budi. Jakarta (ID): Salemba Empat. Strategis dengan Orientasi Global Edisi 2 Jilid 1. Jakarta: Erlangga

Dedi, A.K. 2014. Prospek Kelayakan dan Strategi Pengembangan Pembenihan Ikan Lele (Clarias Sp.) Di Desa Babakan, Kecamatan Ciseeng, Kabupaten Bogor. [Tesis]. Bogor: Institut Pertanian Bogor.
Jaja, A. Suryani, K. Sumantadinata. 2012. Usaha pembesaran dan pemasaran ikan lele serta strategi pengembangannya di UD sumber rezeki parung, Jawa Barat. Jurnal Manajemen IKM, 8(1): 45-56.

Jatnika, D. 2011. Strategi Pengembangan Usaha Budidaya Ikan LELE (Clarias sp.) di Lahan kering di Kabupaten Gunungkidul, Provinsi Daerah Istimewa Yogjakarta. [tesis]. Bogor (ID): IPB

Julisar dan E. Miranda. 2013. Pemakaian ECommerce untuk Usaha Kecil Dan Menengah Guna Meningkatkan Daya Saing. Information Systems Department, School of Information Systems, Binus University. Jurnal ComTech, 4(2).

[KKP] Kementerian Kelautan dan Perikanan Republik Indonesia. 2015. Potensi usaha budidaya ikan air tawar [internet]. [diacu 2018 Mei 17]. Tersedia dari: https://news. kkp. go.id/index.php/

[KKP] Kementerian Kelautan dan Perikanan Republik Indonesia. 2018. Produktivitas Perikanan Indonesia [internet]. [diacu 2018 Mei 17]. Tersedia dari: https://kkp.go.id/ wpcontent/upload

Rangkuti, F. 2008. Analisis SWOT Teknik Membedah Kasus Bisnis. Jakarta (ID): PT Gramedia Pustaka Utama.

Setyorini, E.S. 2018. STRATEGI pemasaran produk olahan hasil perikanan pada UMKM Cindy Group. [tesis]. Bogor(ID): IPB

Sofyan, S., Sugiono. 2003. Metode Riset Penelitian Kuantitatif, kualitatif. Jakarta: Penerbit Gramedia

Suhendar, U. 2009. Kajian strategi pemasaran ikan asap (Smoked Fish) di UKM Petikan Cita Halus Citayam-Bogor. [tesis]. Bogor(ID): IPB

Sulistyowati. 2017. Strategi Pemasaran Ikan Lele "UD Sendang Endah" Di Pasar Rejomulyo Semarang. Agromedia jilid 35 hal 96. 